\title{
Rancang Bangun Alat Hypo-Hyperthermia Berbasis Arduino
}

\author{
Muhammad Ulin Nuha ABA ${ }^{1)}$, Muh. Nauval Karim²), Mohammad Rofi'i ${ }^{3)}$, Diah Rahayu Ningtias ${ }^{4)}$ \\ ${ }^{1,2,3,4)}$ Program Studi Teknik Elektro Medik, Akademi Teknik Elektro Medik Semarang \\ 1,2,3,4)J1. Kol. Warsito Sugiarto KM 2.5 Kel. Sadeng, Kecamatan Gunungpati, Kota Semarang \\ e-mail: $\underline{\text { ulinnuhaaba@atemsemarang.ac.id }}{ }^{1)}, \underline{\text { naufalkarim.16@ gmail.com }}{ }^{2)}, \underline{\text { mrofii@ atemsemarang.ac.id }}{ }^{3)}, \underline{\text { diah- }}^{-}$ \\ rahayu@atemsemarang.ac.id ${ }^{4)}$
}

\begin{abstract}
Hypo-hyperthermia tool is a devive that can stabilize body temperature which decreases or increases temperature dramatically. The design of hypo-hyperthermia devices has been made using Arduino Uno. Functional tests have also been carried out on the hypo-hyperthermia tool to determine the level of success and eligibility. This tool works by utilizing the flow of water to provide the temperature needed by the patient in order to obtain a normal temperature, namely by increasing the temperature of the blanket when the patient has hypothermia and lowering the temperature of the blanket when the patient has hyperthermia. The design of this hypo-hyperthermia tool uses Arduino uno as a processor and DS18B20 sensor for temperature readings. Heaters are also used as water heaters, condensers as water coolers, and water pumps to drive the water cycle from the appliance to the blanket and back to the appliance. The temperature and mode settings will be displayed on the LCD screen. Function test results obtained by comparing the value of the temperature reading in skin mode with a digital thermometer that is obtained an error value of $0.3 \%$. This temperature difference is affected by the room temperature and body temperature of the patient which can change at any time. It was also obtained by comparison of the temperature reading values in blanket mode with a digital thermometer that is obtained the largest error value of $6 \%$ at a setting value of $25{ }^{\circ} \mathrm{C}$ and the smallest error value of $0.3 \%$ at a setting value of $30^{\circ} \mathrm{C}$. This temperature difference is influenced by the temperature of the room at the time of measurement on the blanket is also influenced by the thickness of the hose installed on the blanket, so that the cold temperature in the water is not absorbed properly.
\end{abstract}

Keywords: hypo-hyperthermia, arduino, body temperature

\begin{abstract}
ABSTRAK
Alat Hypo-hyperthermia merupakan alat yang dapat menstabilkan suhu badan yang mengalami penurunan ataupun kenaikan suhu secara derastis. Rancang bangun alat hypo-hyperthermia telah dibuat dengan menggunakan arduino uno. Juga telah dilakukan uji fungsi pada alat hypo-hyperthermia tersebut untuk mengetahui tingkat keberhasilan dan kelayakannya. Alat ini bekerja dengan memanfaatkan aliran air untuk memberikan suhu yang dibutuhkan pasien agar didapatkan suhu normal, yaitu dengan cara menaikkan suhu selimut pada saat pasien mengalami hypothermia dan menurunkan suhu selimut pada saat pasien mengalami hyperthermia. Perancangan alat hypo-hyperthermia ini menggunakan Arduino uno sebagai prosessor dan sensor DS18B20 untuk pembacaan suhu. Juga digunakan heater sebagai pemanas air, kondensor sebagai pendingin air, serta pompa air sebagai penggerak siklus air dari alat menuju selimut dan kembali ke alat. Adapun pengaturan suhu dan mode akan ditampilkan pada layar LCD. Hasil uji fungsi diperoleh perbandingan nilai pembacaan suhu pada mode skin dengan thermometer digital yaitu didapatkan nilai kesalahan sebesar 0,3\%. Perbedaan suhu ini dipengaruhi oleh suhu ruangan dan suhu tubuh pasien yang dapat berubah setiap saat. Selain itu juga diperoleh perbandingan nilai pembacaan suhu pada mode blanket dengan thermometer digital yaitu didapatkan nilai kesalahan terbesar sebesar $6 \%$ pada nilai settingan $25^{\circ} \mathrm{C}$ dan nilai kesalahan terkecil sebesar 0,3\% pada nilai settingan $30^{\circ} \mathrm{C}$. Perbedaan suhu ini dipengaruhi oleh suhu ruangan pada saat dilakukannya pengukuran pada blanket juga dipengaruhi oleh terlalu tebalnya selang yang dipasang pada selimut, sehingga suhu dingin pada air tidak terserap dengan baik.
\end{abstract}

Kata Kunci: hypo-hyperthermia, arduino, suhu tubuh

\section{Pendahuluan}

$\mathrm{E}$ emakin banyak pula terciptanya alat-alat kesehatan (medik) yang serba modern dan otomatis. Peralatan kesehatan sebagai bagain dari alat elektromedik juga mengalami modernisasi, salah satunya alat hypo-hyperthermia yang berfungsi untuk menstabilkan suhu tubuh bagi pasien yang menderita penyakit hipotermia (hypothermia) dan hipertermia (hy- perthermia). Seperti yang kita ketahui, suhu tubuh merupakan hal penting yang harus diperhatikan sebagai salah satu tanda vital suatu individu [1].

Selama proses operasi (bedah anestesi) biasanya suhu pasien akan berubah secara drastis. Salah satu faktor bisa diakibatkan karena penggunaan beberapa anestetik yang memiliki efek samping penurunan suhu tubuh [2]. Penurunan suhu tubuh di bawah 360C disebut hipotermia [3]. Selain penurunan suhu tubuh, hal lain 
yang dapat terjadi selama proses anestesi adalah kenaikan suhu tubuh yang tinggi. Suhu tubuh yang terlalu panas atau tinggi yaitu diatas 37.50C disebut hipertermia [4]. Ketika pasien mengalami hypothermia beberapa fungsi organ vital akan menurun kinerjanya. Sedangkan ketika pasien mengalami hyperthermia pasien akan mengalami kejang-kejang. Berdasarkan penelitian Harahap (2014) tentang kejadian hipotermia di Rumah Sakit Dr. Hasan Sadikin Bandung, menyatakan bahwa angka kejadian hipotermia di ruang pemulihan pada pasien yang menjalani operasi adalah sebanyak $87,6 \%$. Kejadian hipotermia menyebabkan lama perawatan di ruang pemulihan meningkat [5].

Berbagai upaya untuk mengurangi kejadian hipotermia maupun hipertermia sudah banyak dilakukan seperti dengan penggunaan Sleepingbag [6] juga blanket warmer [7]. Berdasarkan penelitian Ramadhan (2018) menunjukkan bahwa pengontrolan suhu tubuh pada pasien atau seseorang dapat dilakukan dengan menggunakan sleepingbag. Sleepingbag tersebut menggunakan sensor pulse yang terhubung dengan mikrokontroler arduino nano yang mampu melakukan tindakan pencegahan pada penderita hipotermia. Penelitian lain oleh Rositari (2017), menyebutkan pemberian blanket warmer efektif untuk menormalkan suhu pada pasien pasca bedah sectio caesaria yang mengalami hipotermia.

Pada kasus hipertermia, Intervensi untuk menurunkan demam dapat dilakukan dengan pemberian terapi non farmakologi. Salah satunya adalah metode kompres dan aliran udara dingin, yaitu dengan kompres dingin di dada pasien dan mengalirkan udara dingin ketubuh pasien sehingga suhu tubuh turun 1 sampai 20C setelah dilakukan tindakan selama 5 sampai 7 jam [8]. Selain itu juga biasa digunakan kompres hangat untuk mengatasinya [9]. Hal ini juga diperkuat oleh penelitian Priyanto (2016) yang menyatakan bahwa pemakaian kompres hangat dianjurkan sebagai terapi kombinasi dengan antipiretik untuk membantu menurunkan temperature tubuh [10]. Namun pada kasus yang membutuhkan penanganan cepat seperti pada saat proses operasi (bedah anestesi), penggunaan kompres hangat kuranglah efektif. Untuk itu digunakan sebuah alat cooling blanket untuk menurunkan suhu tubuh pada pasien [11]. Alat cooling blanket ini menggunakan sebuah selimut yang dialiri air dingin serta mampu menurunkan suhu sekitar 40C dari suhu awal [12].

Berdasarkan uraian diatas jelas bahwa penggunaan alat untuk mengatasi kejadian hypothermia maupun hyperthermia sangatlah penting. Namun alat yang ada di rumah sakit hanya mampu mengatasi satu permasalahan saja, yaitu hipotermia atau hipertermia. Sehingga diperlukan sebuah peralatan yang dapat sekaligus mengatasi hypothermia maupun hyperthermia. Pembuatan sistem rancang bangun hypothermia maupun hyperthermia ini mengacu pada penelitian sebelumnya yaitu penelitian
Tulak (2018) yang membuat alat warming bed berbasis arduino uno dengan menggunakan heater dan sensor suhu [13]. Selain itu juga penelitian oleh Negoro (2018) yang membuat alat pendeteksi parameter tanda vital tubuh manusia termasuk suhu tubuh dengan menggunakan sensor DS18B20 [14]. Penelitianpenelitian tersebut selanjutnya dapat diadopsi untuk membuat rancang bangun hypo-hyperthermia dengan menambahkan sistem pendingin sebagai penanganan pasien hyperthermia menggunakan sistem berbasis mikrokontrolleryang dapat digunakan dalam menunjang kegiatan pelayanan kesehatan di rumah sakit.

\section{Hypothermia}

\section{TINJAUAN PUSTAKA}

Hypothermia didefinisikan sebagai kondisi klinis ketika suhu internal (Rektrum, esophagus atau timpani), kurang dari $35^{\circ} \mathrm{C}$. American Collageof Surgeons mengenali tiga derajat hypothermia yakni ringan (35$32^{\circ} \mathrm{C}$ ), sedang $\left(32-30{ }^{\circ} \mathrm{C}\right)$, berat (dibawah $\left.30^{\circ} \mathrm{C}\right)$. Suhu terendah pada anak yang mampu selamat adalah $14,4^{\circ} \mathrm{C}$, sedangkan pada orang dewasa adalah $13,7^{\circ} \mathrm{C}$.

Hypothermia sering terjadi pada pasien pasca operasi. Turunnya suhu badan yang disebabkan oleh rendahnya suhu ruangan selama dan pasca operasi menjadi faktor utama yang mengakibatkan pasien mengalami penurunan suhu tubuh secara drastis, dalam kasus ini beberapa peneliti mem-presentase-kan bahwa "Satu dari tiga pasien mengalami hypothermia selama operasi bila tidak dilakukan intervensi. Sekitar 30 sampai $40 \%$ pasien pasca anestesi ditemukan dalam keadaan hypothermiaketika tiba di ruang pemulihan".

Dampak negatif yang terjadi ketika pasien mengalami hypothermia akan mengakibatkan resiko yang berbahaya bagi pasien. Diantara resiko-resiko tersebut adalah resiko perdarahan meningkat, iskemia miokardium, pemulihan pasca anastesi yang lebih lama, gangguan penyembuhan luka, serta meningkatnya resiko infeksi. Hypothermia akan menambah kebutuhan oksigen, kadar karbon dioksida, dan juga peningkatan katekolamin didalam plasma yang akan diikuti dengan peningkatan laju nadi, tekanan darah, serta curah jantung. Tentunya Keadaan ini sangat tidak menguntungkan bagi pasien [15].

\section{Hyperthermia}

Hyperthermia merupakan kondisi klinis ketika suhu tubuh tidak dapat mempertahankan suhu normalnya sehingga suhu badan naik secara drastis. Suhu tubuh pasien yang mengalami hyperthermia biasanya diatas $38^{\circ} \mathrm{C}$. Selain faktor lingkungan yang dapat mengakibatkan hyperthermia, beberapa faktor lain pun dapat mengakibatkan hyperthermia diantaranya adalahkecepatan metabolisme basal, rangsangan saraf simpatis, hormon pertumbuhan, hormon tiroid, hormon kelamin, 
proses peradangan, status akitivitas, gangguan organ dan lingkungan [8].

\section{Water Heater}

WaterHeater(pemanas air) merupakan alat yang digunakan untuk memanaskan air yang mneggunkaan energi sebagai sumber pemanas, yaitu listrik, gas atau matahari. Dari ketiga jenis sumber energy yang digunakan tersebut energy listrik lebih banyak digunakan karena lebih praktis dalam penggunaan dan pemaangannya [16].

\section{Kondensor}

Kondensor adalah alat untuk membuat kondensasi bahan pendingin gas dari kompresor dengan suhu tinggi dan tekanan tinggi. Untuk penempatanya sendiri, kondensor ditempatkan diluar ruangan yang sedang didinginkan, agar dapat membuang panasnya keluar. Kondensor merupakan jaringan pipa yang berfungsi sebagai pengembunan. Refrigerant yang dipompakan dari kompresor akan mengalami penekanan sehingga mengalir ke pipa kondensor kemudian mengalami pengembunan. Dari sini refrigerant yang sudah mengembun dan menjadi zat cair akan mengalir menuju pipa evaporator [17].

\section{Arduino}

Arduino unoadalah arduino board yang menggunakan mikrokontroler ATmega328. Arduino memiliki 14 pin digital (6 pin dapat digunakan sebagai output PWM), 6 input analog, sebuah $16 \mathrm{MHz}$ osilator Kristal, sebuah koneksi USB, sebuah konektor sumber tegangan, sebuah header ICSP, dan sebuah tombol reset. Arduino uno memuat segala hal yang dibutuhkan untuk mendukung sebuah mikrokontroler. Hanya dengan menghubungkannya ke sebuah komputer melalui USB atau memberikan tegangan DC dari baterai atau adaptor sudah dapat membuatnya bekerja [18]. Gambar modul arduino ditunjukkan oleh gambar 1.

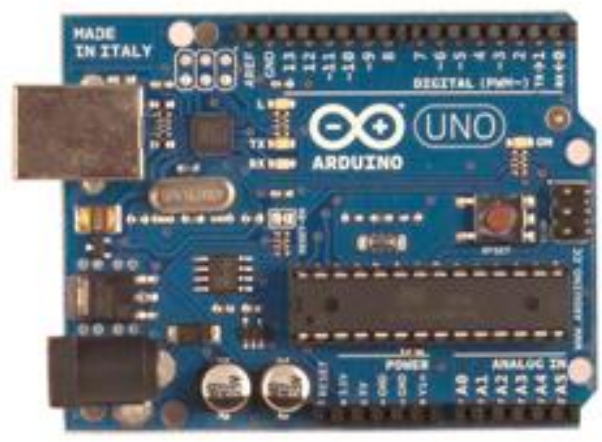

Gambar 1. Modul Arduino

\section{Pompa Air}

Pompa merupaka alat atau mesin yang digunakan untuk memindahkan cairan dari suatu tempat ke tempat yang lain melalui suatu media perpipaan dengan cara menambahkan energi pada cairan yang dipindahkan dan berlangsung secara terus menerus.

Pompa air yang ditunujukan pada beroperasi dengan prinsip membuat perbedaan tekanan antara bagian masuk (suction) dengan bagian keluar (discharge). Dengan kata lain, pompa berfungsi mengubah tenaga mekanis dari suatu sumber tenaga (penggerak) menjadi tenaga kinetis (kecepatan), dimana tenaga ini berguna untuk mengalirkan cairan dan mengatasi hambatan yang ada [19].

\section{METODE}

Rancang bangun alat hypo-hyperthermia ini menggunakan beberapa komponen seperti Arduino Uno, water heater, kondensor, pompa air serta sensor. Arduino uno ini berfungsi sebagai prosesor yang memuat segala hal yang dibutuhkan untuk mendukung sebuah mikrokontroler [18] water heater digunakan untuk memanaskan air dengan menggunakan energi sebagai sumber pemanas [16], kondensor digunakan untuk melepaskan kalor atau sebagai pendingin air [17], sensor digunakan untuk pembacaan suhu, dan pompa air berfungsi sebagai penggerak siklus air dari alat menuju selimut dan kembali ke alat. Keseluruhan komponen tersebut selanjutnya dirangkai sebagai sebuah alat yang dapat menstabilkan suhu pasien pada saat dan pasca operasi.

\section{Blok diagram}

Blok diagram hypo-hyperthermia ditunjukkan pada Gambar 2 yang menjelaskan prinsip pengendali alat secara umum. Secara umum alat ini menggunakan mikroprosessor Arduino uno serta beberapa sensor yaitu, Flow sensor, sensor suhu, serta skin sensor. Flow sensor berfungsi untuk mendeteksi aliran air, sensor suhu berfungsi untuk mendeteksi suhu yang telah tercapai pada blanket/selimut, sedangkan skin sensor berfungsi sebagai pendeteksi suhu pada pasien. Ketika aliran air mulai melemah, maka sensor akan mengirimkan sinyal ke mikroprosessor dan menampilkannya ke display.

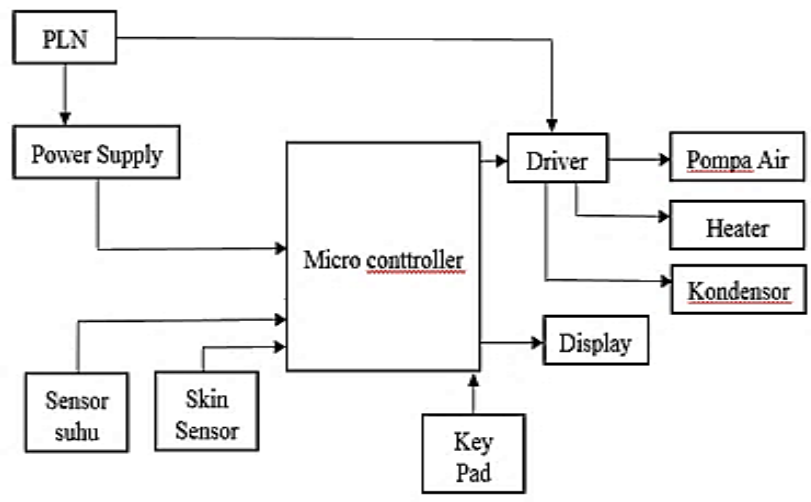

Gambar 2. Blok diagram 


\section{Prinsip Operasi Alat}

Secara umum prinsip operasi alat ditunjukkan oleh diagram alir pada Gambar 3. Pertama kali program akan menginisialisasi alat, kemudian program akan menampilkan nama alat sebelum masuk pada pengaturan suhu. Selanjutnya program akan menerima perintah pengaturan suhu yang di atur oleh pengguna (user). Program akan memberikan perintah/mengendalikan kerja dari pendingin dan pemenas sesuai perintah pengguna. Apabila suhu yang telah diatur belum tercapai, maka program akan mengulangi perintah tersebut hingga suhu tercapai. Setelah suhu tercapai, alat akan standby.

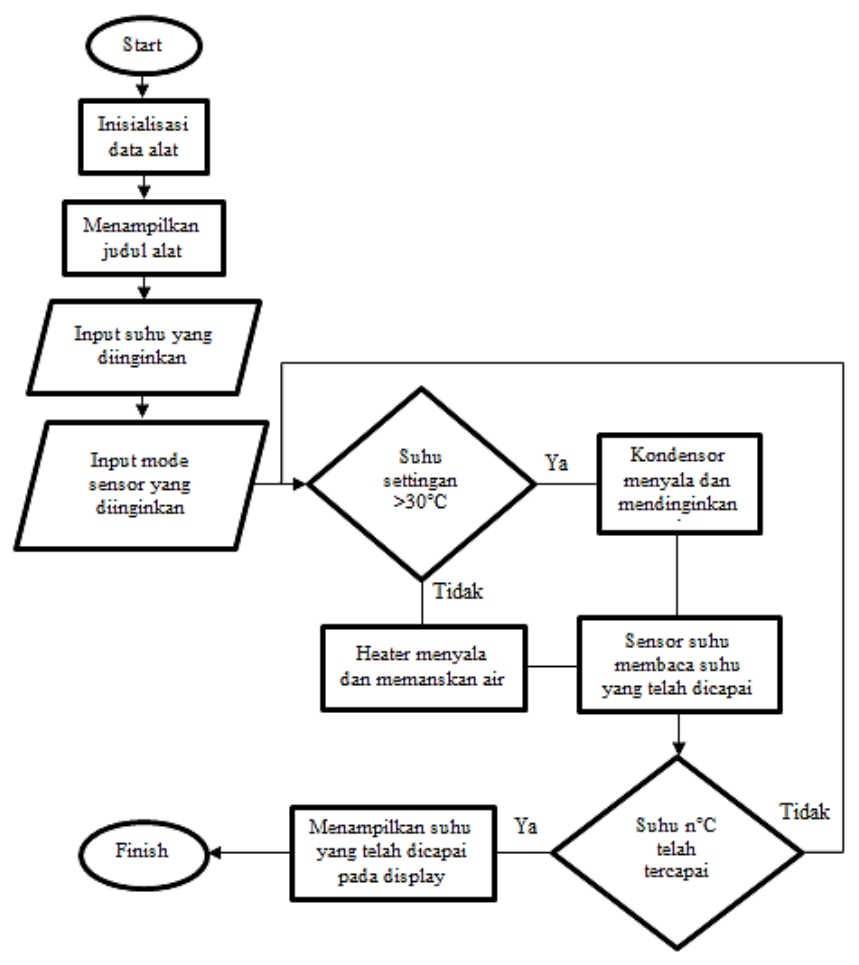

Gambar 3. Diagram alirprinsip operasi alat

\section{Desain alat}

Gambar4 merupakan gambar desain alat hypo-hyperthermia:

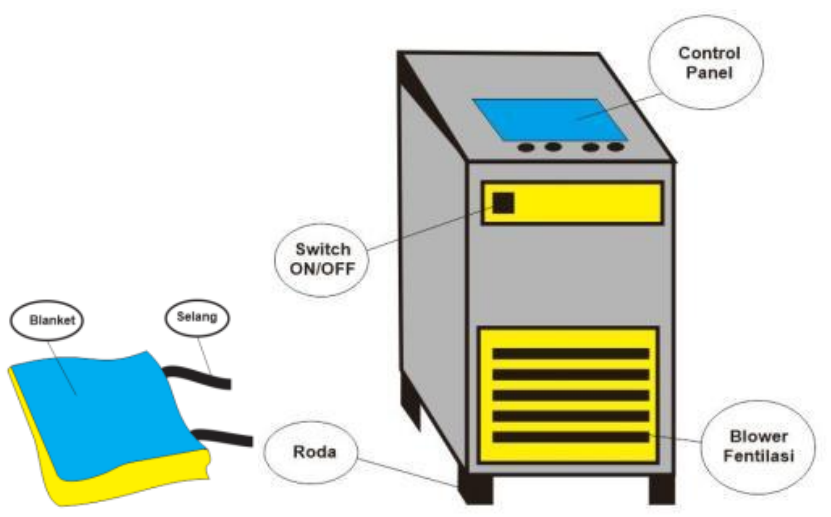

Gambar 4. Desain alat
Beberapa bagian pada alat yang ditunjukkan pada Gambar 4 memiliki fungsi masing-masing. Control Panel berfungsi sebagai pusat pengontrolan alat, blower ventilasi berfungsi sebagai tempat keluarnya udara panas pada alat, roda berfungsi untuk penggerak alat, serta switchOn/Off berfungsi sebagai saklar alat.

\section{RancanganSoftware}

Berikut adalah listing program alat hypo-hyperthermia menggunakan software arduino.

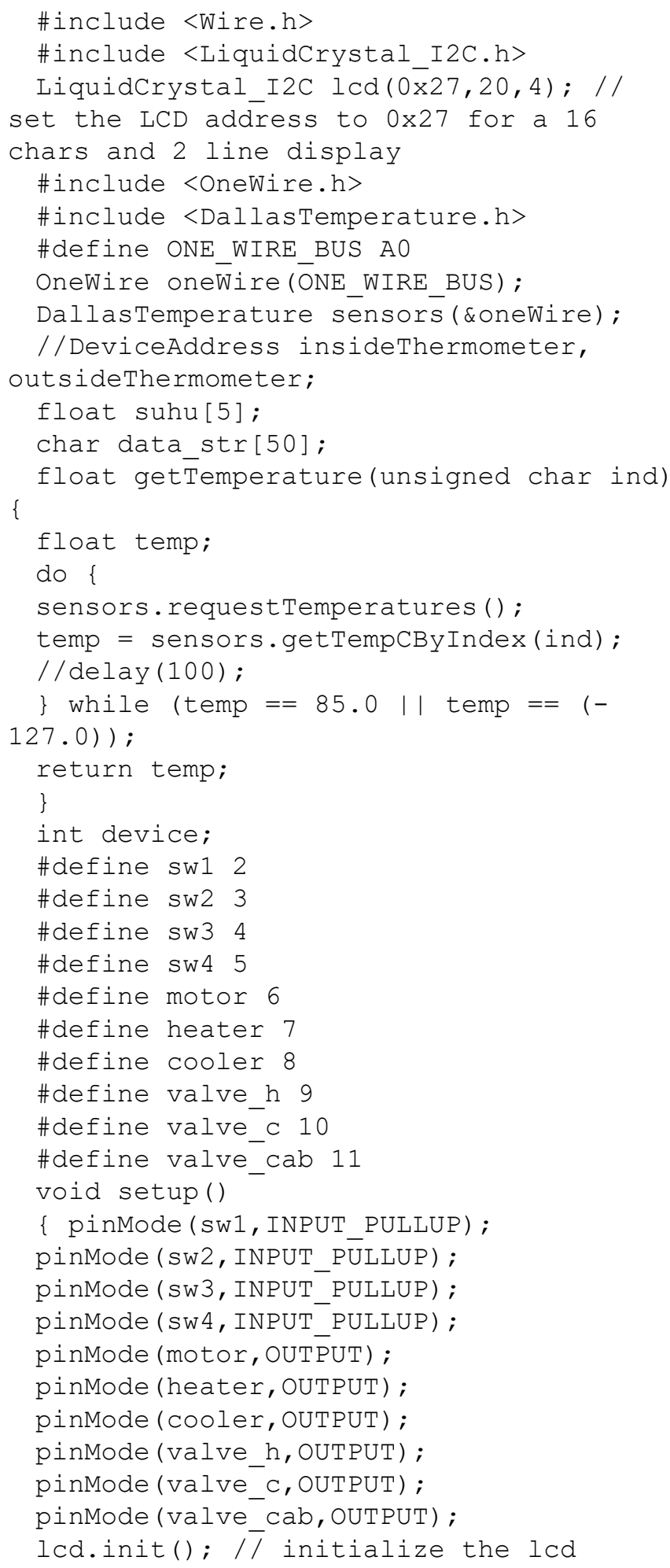




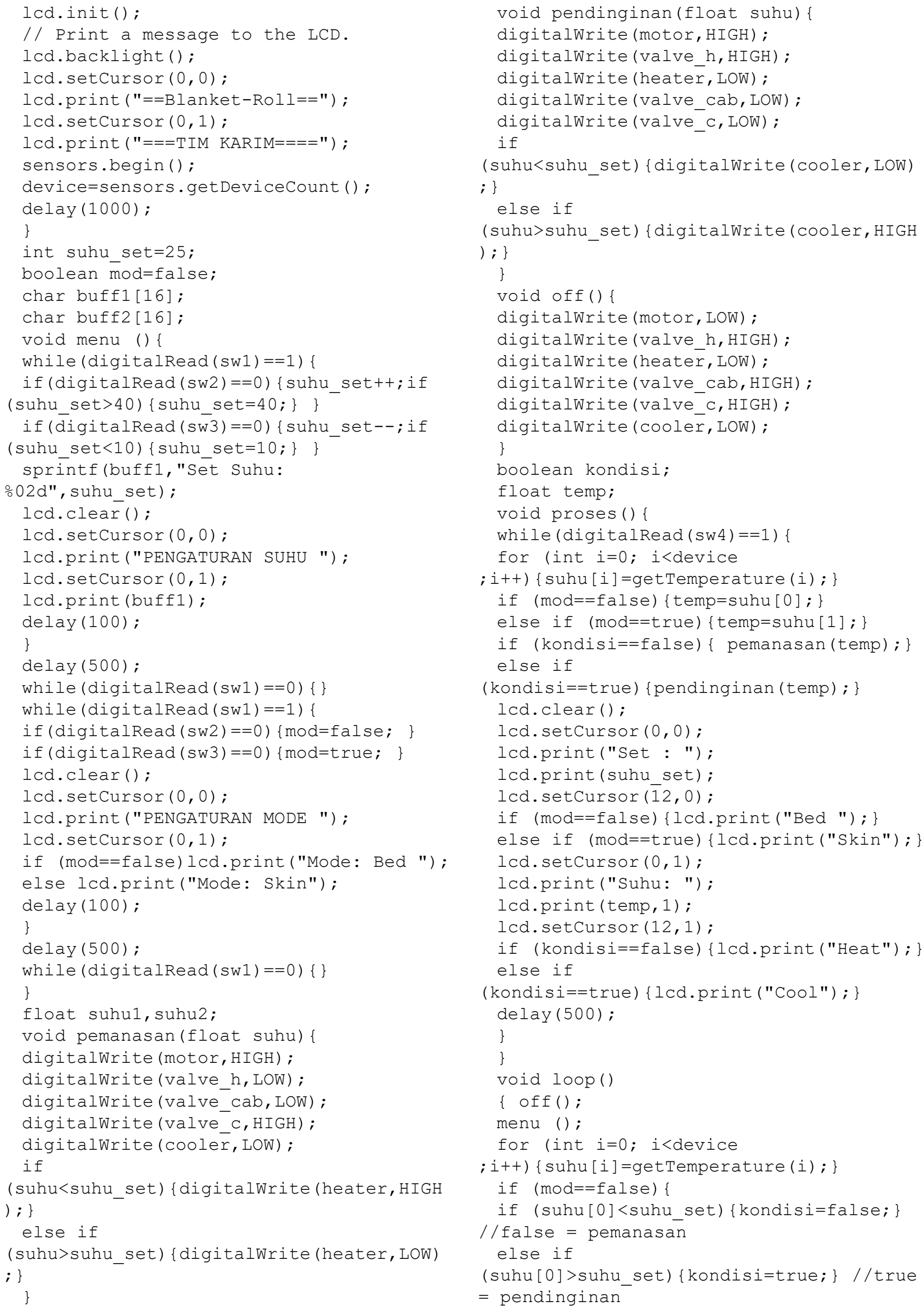




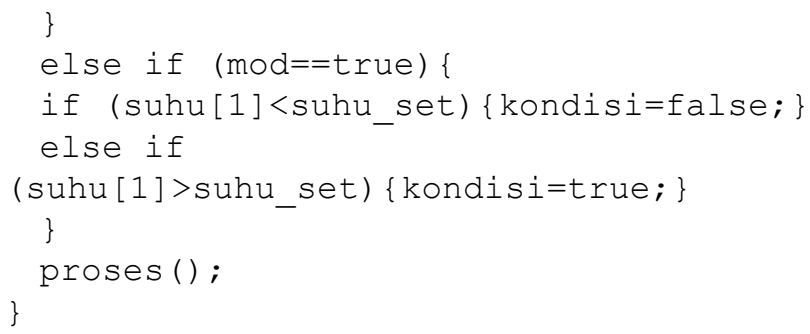

\section{Perancangan sistem alat}

Skematik rangkaian keseluruhan alat ditunjukkan oleh Gambar 5. Pada saat alat mati, tekan tombol on pada switch kemudian power supply akan menyala dan menyuplai tegangan keseluruh rangkaian. Arduino uno akan menyala yang berfungsi sebagai prosessor untuk menampilkan perintah pada LCD16X2 dan push button berfungsi sebagai tombol pilihan perintah yang dikirim ke arduino uno yang selanjutnya akan ditampilkan pada LCD 16X2.

Ketika arduino uno telah menerima perintah pengaturan suhu, arduino uno akan memberikan logic tertentu untuk mengatur kerja dari flow switch yang menjadi gerbang pilihan air yang akan digunakan. setelah air disirkulasi melalui pompa menuju selimut, kemudian sensor DS18B20 akan mendeteksi perubahan suhu yang terjadi pada selimut. Hasil pembacaan sensor DS18B20 akan dikirim ke arduino uno dan akan ditampilkan pada LCD 16X2.

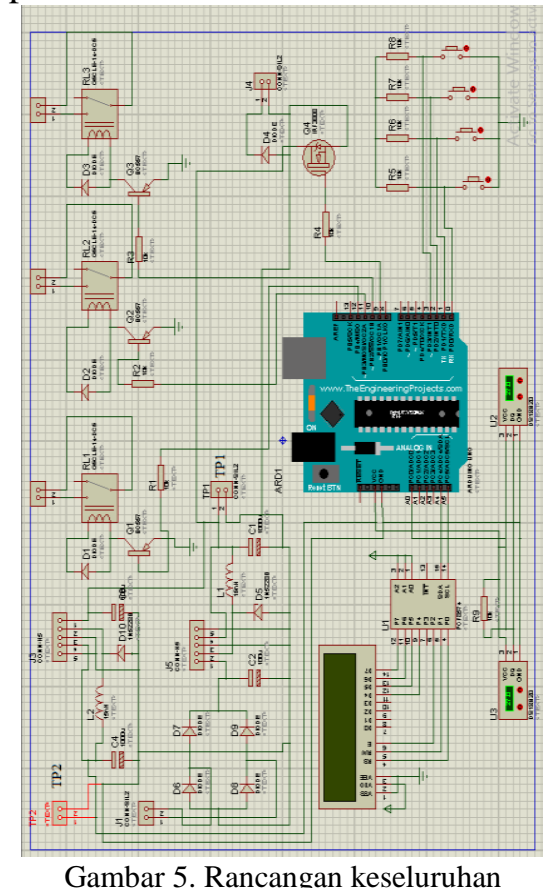

\section{HASIL DAN PEMBAHASAN}

Rancang bagun alat hypo-hyperthermia telah berhasil dibuat dengan baik dengan mengadopsi dan modifikasi penelitian yang dilakukan oleh Tulak (2018). Sistem warming bed berbasis arduino uno yang diusung oleh Tulak (2018) untuk mengontrol heater dan sensor suhu sejalan dengan sistem pada rancang bangun alat hypo-hyperthermia pada penelitian ini. Adapun sensor suhu yang digunakan adalah sensor DS18B20 seperti pada penelitian Negoro (2018). Pemilihan sensor ini dikarenakan memiliki karakteritik waterproof (tahan air). Selain itu berdasarkan penelitian Rozaq (2017) yang telah melakukan uji karakteristik terhadap sensor DS18B20, menyatakan bahwa tingkat kesalahan sensor tersebut adalah tidak lebih dari $2 \%$ sehingga dapat digunakan dalam pengukuran suhu [20].

Setelah komponen dirangakai menjadi modul (alat telah jadi), selanjutnya dilakukan pengujian beberapa titik pengukuran yang dapat mewakili kondisi rangkaian alat secara menyeluruh. Ada 4 titik pengukuran yang dipilih yaitu Titik Pengukuran 1 (TP1), Titik Pengukuran 2 (TP2), Titik Pengukuran 3 (TP3) dan Titik Pengukuran 4 (TP4). TP1 yaitu titik pengukuran yang berada pada outputpower supply, TP2 yaitu titik pengukuran yang berada pada inputmicroprocessor, TP3 yaitu titik pengukuran pada pembacaan sensor suhu pada mode skinsensor, dan TP4 yaitu titik pengukuran pada pembacaan sensor suhu pada mode blanket.

\section{Hasil dan Analisis Titik Pengukuran (TP1)}

Pengukuran TP1 dilakukan pada sumber daya (powersupply). Pengukuran menggunakan multimeter digital dengan cara mengukur keluaran dari power supply dengan probe multimeter digital. Sebelum melakukan pengukuran selector pada multimeter digital dipindahkan ke pilihan DC. Probe yang berwarna hitam ditempatkan pada keluaran negatif (-) power supply dan probe merah ditempatkan pada keluaran positif (+) power supply. Hasil pengambilan sample data ditunjukkan pada Tabel 1 yang kemudian akan dihitung persentasi kesalahannya.

Tabel 1. Pengukuran 1

\begin{tabular}{|c|c|c|c|}
\hline \multicolumn{3}{|c|}{ Hasil pengukuran } & \multirow[b]{2}{*}{$\begin{array}{l}\text { DataSheet } \\
\text { (VDC) }\end{array}$} \\
\hline $\begin{array}{c}\text { Pen- } \\
\text { gukuran }\end{array}$ & $\begin{array}{l}\text { Tegangan } \\
\text { VDC }\end{array}$ & $\begin{array}{c}\text { Rata- } \\
\text { Rata } \\
\text { (VDC) }\end{array}$ & \\
\hline 1 & 12,2 & \multirow{4}{*}{11,92} & \multirow{4}{*}{12} \\
\hline 2 & 11,7 & & \\
\hline 3 & 12 & & \\
\hline 4 & 11,8 & & \\
\hline
\end{tabular}

\section{Hasil dan Analisis Titik Pengukuran 2 (TP 2)}

Pengukuran TP2 adalah pengukuran keluaran powersupply 5 VDC untuk memberikan supply tegangan ke mikrokontroler. Pengukuran dilakukan dengan menggunakan multimeter digital dengan cara mengukur keluaran dari power supply dengan probe multimeter digital. Seperti halnya pada TP1, sebelum melakukan pengukuran selector pada multimeter digital dipindahkan ke pilihan DC. Probe yang berwarna hitam 
ditempatkan pada keluaran negatif (-) power supply dan probe merah ditempatkan pada keluaran positif $(+)$ power supply. Hasil pengambilan sample data ditunjukkan pada Tabel 2 yang kemudian akan dihitung persentasi kesalahan.

Tabel 2. Pengukuran 2

\begin{tabular}{|c|c|c|c|}
\hline \multicolumn{3}{|c|}{ Hasil pengukuran } & \multirow[b]{2}{*}{$\begin{array}{c}\text { DataSheet } \\
\text { (VDC) }\end{array}$} \\
\hline $\begin{array}{l}\text { Penguku- } \\
\text { ran }\end{array}$ & $\begin{array}{c}\text { Tegangan } \\
\text { VDC }\end{array}$ & $\begin{array}{c}\text { Rata- } \\
\text { Rata } \\
\text { (VDC) }\end{array}$ & \\
\hline 1 & 5,2 & \multirow{4}{*}{5,08} & \multirow{4}{*}{5} \\
\hline 2 & 5,3 & & \\
\hline 3 & 5 & & \\
\hline 4 & 4,8 & & \\
\hline
\end{tabular}

Hasil dan Analisis Titik Pengukuran 3 (TP 3)

Pengukuran TP3 dilakukan untuk membandingkan pembacaan sensor pada mode kulit (skin mode) dengan thermometer digital untuk mengetahui tingkat kesalahan pembacaan sensor suhu pada alat hypo-hyperthermiadengan menggunakan 2 responden dan 3 kali pengukuran pada setiap responden. Hasil pengukuran dapat dilihat pada Tabel 3.

Tabel 3. Perbandingan suhu hypo-hyperthermiadan thermometerpada TP 3

\begin{tabular}{|c|c|c|c|c|c|c|}
\hline \multirow[b]{2}{*}{$\begin{array}{l}\mathrm{N} \\
\mathrm{O}\end{array}$} & \multirow[b]{2}{*}{$\begin{array}{c}\text { Sam- } \\
\text { pel }\end{array}$} & \multicolumn{2}{|c|}{ Alat Peneliti } & \multicolumn{2}{|c|}{ Thermometer } & \multirow[b]{2}{*}{$\begin{array}{c}\text { Kesala- } \\
\text { han }\end{array}$} \\
\hline & & $\begin{array}{c}\text { Suhu } \\
\text { Tubu } \\
\text { h }\end{array}$ & $\begin{array}{l}\text { Rat } \\
\text { a- } \\
\text { rata }\end{array}$ & $\begin{array}{c}\text { Suhu } \\
\text { Tub } \\
\text { uh }\end{array}$ & $\begin{array}{c}\text { Rata- } \\
\text { rata }\end{array}$ & \\
\hline \multirow{3}{*}{1} & \multirow{3}{*}{ A } & $35,8^{\circ}$ & \multirow{3}{*}{$\begin{array}{c}35 \\
9^{\circ}\end{array}$} & $\underset{\circ}{35,9}$ & \multirow{3}{*}{$36^{\circ}$} & \multirow{3}{*}{$0,3 \%$} \\
\hline & & $35,9^{\circ}$ & & $36^{\circ}$ & & \\
\hline & & $36^{\circ}$ & & $\underset{\circ}{36,1}$ & & \\
\hline \multirow{3}{*}{2} & \multirow{3}{*}{ B } & $36,1^{\circ}$ & \multirow{3}{*}{$36^{\circ}$} & $36^{\circ}$ & \multirow{3}{*}{$36,1^{\circ}$} & \multirow{3}{*}{$0,3 \%$} \\
\hline & & $36^{\circ}$ & & $\begin{array}{c}36,1 \\
0\end{array}$ & & \\
\hline & & $35,9^{\circ}$ & & $\begin{array}{c}36,2 \\
0\end{array}$ & & \\
\hline
\end{tabular}

Pada hasil pengujian terdapat perbedaan hasil antara alat dengan thermometer. Perbedaan hasil suhu ini terjadi akibat pengaruh perubahan suhu ruangan dan suhu tubuh badan yang dapat berubah setiap saat.

\section{Hasil dan Analisis Titik Pengukuran 4 (TP4)}

Pengukuran yang dilakukan pada titik pengukuran 4 (TP4) ini bertujuan untuk membandingkan pembacaan sensor pada mode blanket mode dengan thermometer digital. Hasil dari TP4 digunakan untuk mengetahui tingkat kesalahan pembacaan sensor suhu pada alat hypo-hyperthermia. Hasil pengukuran dapat dilihat pada Tabel 4.
Tabel 4. Perbandingan suhu hypo-hyperthermia dan thermometer pada TP 4

\begin{tabular}{|c|c|c|c|c|}
\hline \multirow[b]{2}{*}{ No } & \multirow[b]{2}{*}{$\begin{array}{l}\text { Nilai set- } \\
\text { ting }\end{array}$} & \multicolumn{2}{|c|}{ Alat Peneliti } & \multirow[b]{2}{*}{ Kesalahan } \\
\hline & & $\begin{array}{c}\text { Suhu } \\
\text { Blanket }\end{array}$ & Rata-rata & \\
\hline 1 & $30^{\circ}$ & $30,3^{\circ}$ & $30,3^{\circ}$ & $0,3 \%$ \\
\hline 2 & $27^{\circ}$ & $26,8^{\circ}$ & $26,8^{\circ}$ & $0,7 \%$ \\
\hline 3 & $25^{\circ}$ & $26,5^{\circ}$ & $26,5^{\circ}$ & $6 \%$ \\
\hline
\end{tabular}

Dari hasil pengukuran Tabel 4 didapatkan nilai kesalahan terbesar adalah $6 \%$ pada nilai settingan $25^{\circ} \mathrm{C}$. Hal ini diakibatkan karena terlalu tebalnya selang yang dipasang pada selimut, sehingga suhu dingin pada air tidak dapat terserap dengan baik. Sedangkan kesalahan terkecil adalah $0,3 \%$ pada nilai setting-an $30^{\circ} \mathrm{C}$. Perbedaan nilai antara suhu Blanket dengan nilai setting selain disebabkan terlalu tebalnya selang pada alat, juga diakibatkan adanya pengaruh suhu ruangan pada saat dilakukannya pengukuran.

\section{KESIMPULAN}

Alat hypo-hyperthermia berhasil dirancang menggunakan Arduino uno sebagai prosessor dengan beberapa komponen pendukung seperti water heater, kondensor serta beberapa sensor. Hasil uji fungsi diperoleh perbandingan nilai pembacaan suhu pada mode skin dengan thermometerdigital yaitu didapatkan nilai kesalahan sebesar $0,3 \%$. Perbedaan suhu ini dipengaruhi oleh suhu ruangan dan suhu tubuh pasien yang dapat berubah setiap saat. Selain itu juga diperoleh perbandingan nilai pembacaan suhu pada mode blanket dengan thermometerdigital yaitu didapatkan nilai kesalahan terbesar sebesar $6 \%$ pada nilai settingan $25^{\circ} \mathrm{C}$ dan nilai kesalahan terkecil sebesar $0,3 \%$ pada nilai settingan $30^{\circ} \mathrm{C}$. Perbedaan suhu ini dipengaruhi oleh suhu ruangan pada saat dilakukannya pengukuran pada blanket juga dipengaruhi oleh terlalu tebalnya selang yang dipasang pada selimut, sehingga suhu dingin pada air tidak terserap dengan baik.

\section{DAFTAR PUSTAKA}

[1] Satria, G.D., Setyo, B., Dinni, N. (2016). Hipotermia dan waktu pemulihannya dalam anestesi gas isofluran dengan induksi ketamin-xylazin pada anjing. Jurnal Veteriner. 17(1):1-6

[2] Noviana, D., \& Gunanti, Ni.R.F.H.J. (2006). Pengaruh anestesi terhadap saturasi oksigen (spo2) selama operasi ovariohisterektomi kucing. J Sain Vet. 24(2): 177-184.

[3] Beattie, C. (2008). Sejarah dan prinsip-prinsip ilmu anestesi dalam gilman dalam dasar farmakologi terapi. Penerbit Buku Kedokteran EGC. 1(10):313-321

[4] Anisa, K.D. (2019). Efektifitas kompes hangat untuk menurunkan suhutubuh pada an.d dengan hipertermia. Jurnal Ilmiah Ilmu Kesehatan. 5(2):122-127 
[5] Harahap, A.M., Rudi K.K., \& Ezra, O.L. (2014). Angka kejadian hipotermia dan lama perawatan di ruang pemulihan pada pasien geriatri pascaoperasi elektif bulan oktober 2011-maret 2012 di Rumah Sakit Dr. Hasan Sadikin Bandung. Jurnal Anestesi Periopratif. 2(37).

[6] Ramadhan, F., Awal, R.M., \& Wijaya, K. (2018). Rancang bangun pengontrolan suhu pada sleepingbag sebagai tindakan pencegahan pada penderita hipotermia. Jurnal Pengembangan Teknologi Informasi dan Ilmu Komputer. 2(10)

[7] Rositari, S., Mulyanto, V. D. (2017). Efektifitas pemberian blanket warmer pada pasien pasca sectio caesaria yang mengalami hipotermi di RS PKU Muhammadiyah Surakarta. Jurnal Ilmu Keperawatan Indoensia. 10(1)

[8] Kurniawan, T. (2018). Kombinasi kompres dingin dan aliran udara dingin terhadap penurunan suhu tubuh pada pasien sepsis dengan hipertermi. Semarang: Program Studi S1 Keperawatan Universitas Muhammadiyah Semarang.

[9] Purwanti, S., Winarsih, N.A. (2008). Pengaruh kompres hangat terhadap perubahan suhu tubuh pada pasien anak hipertermia di Ruang Rawat Inap RSUD Dr. Moewardi Surakarta. Berita Ilmu Keperawatan. 1(2)

[10] Priyanto, H. (2016). Asuhan Keperawatan Pemenuhan Kebutuhan Keamanan Perlindungan termoregulasi dengan hipertermia pada An. F di Ruang Melati RSUD Dr. Soedirman Kebumen. Tugas Akhir. STIKES Muhammadiyah Gombong

[11] Ivandri, Syafri K.A., M. Ramli, Ilhamjaya, P. (Tanpa tahun). Perbandingan efek kombinasi metamizol- cooling blanket dengan parasetamol-cooling blanket dalam menurunkan demam pasien cedera kepala. Makassar: Fakultas Kedokteran Universitas Hasanuddin

[12] Theasianparent.com. Bayi selamat dari maut berkat selimut pendingin. Diakses pada 31 Desember 2019

[13] Tulak, A.N. (2018). Rancang bangun warming bed berbasis arduino uno. Tugas Akhir. Semarang: ATEM Semarang

[14] Negoro, E.D.P. Prototipe alat heartrate, saturasi oksigen, nibp dan suhu tubuh dengan monitoring melalui smartphone android. Tugas Akhir. Semarang: ATEM Semarang

[15] Marisa, Anggita Harahap., Rudi K. Kadarsah., Ezra Okta Liansah. 2012. Angka Kejadian Hipotermia dan Lama Perawatan di Ruang Pemulihan pada Pasien Geriatri Pascaoperasi Elektif. Jurnal Anestesi Periopratif. 2: 37.

[16] Rokhandi, Z., Binsar, P. (2017). Simulator pengatur otomatis suhu air hangat 370C - 550C pada water heater berbasis microkontroller Atmega 8535. Jurnal Teknologi Elektro. 8(3). Universitas Mercu Buana

[17] Kristanto. (2009). Rancang bangun dan pengujian model kondensor tipe concentric tube counter current tunggal dipasang vertical. Surakarta: Fakultas Teknik Mesin Muhammadiyah Surakarta
[18] Dinata, Y.M. (2014). Arduino itu mudah. Surabaya: PT Elex Media Komputindo

[19] Wardjito. (2012). Perencanaan instalasi pompa return pump dengan kapaitas $130 \mathrm{~m} 3 / \mathrm{jam}$ untuk exchanger heater ammonia. Jurnal Wahana Teknik. Volume 01, Nomor 01. Gresik.

[20] Rozaq, I.A., Noor, Y.D.S. (2017). Uji karakterisasi sensor suhu DS18B20 waterproof berbasis arduino uno sebagai salah satu parameter kualitas air. Prosiding SNATIF Ke-4. Bandung: Fakultas Teknik Universitas Muria Kudus 